\title{
1. Entrepreneurial marketing: Entrepreneurship and marketing interface
}

\subsection{CHAPTER OBJECTIVES}

- To define the concept of marketing.

- To define entrepreneurship from different perspectives.

- To elaborate on the entrepreneurial marketing concept.

- To understand the entrepreneurial marketing dimensions.

- To understand the $4 \mathrm{Ps}, 4 \mathrm{Cs}, 4 \mathrm{Vs}, 4 \mathrm{Os}$, and $4 \mathrm{As}$ of the marketing mix.

\subsection{PROFILE: STEVE JOBS AND APPLE INC.}

Steve Jobs was born on February 24, 1955 in San Francisco, California. His parents, two University of Wisconsin graduate students, Joanne Schieble (a speech therapist) and Abdulfattah John Jandali (a Syrian political science professor), gave him up for adoption at birth without giving him a name. Steve was adopted by Clara (an accountant) and Paul (a machinist and Coast Guard veteran) Jobs. They named him Steven Paul Jobs. Having grown up in flourishing Silicon Valley in the 1960s and 1970s, Steve Jobs emerged as a young success, taking interest in the surrounding technology industry, and eventually dropping out of college while starting Apple with another young technical mind, Steve Wozniak. They had met at the age of 13 and together founded Apple in 1976.

While their success in selling computers, particularly the Apple II, launched Apple into early success, competing for market share with established firms such as IBM was a major hurdle. By the mid-1980s, Jobs had been pushed out of his own billion-dollar company due mainly to irreconcilable differences of vision between him and Apple's board. That did not stop or even slow Jobs's drive and passion, and Jobs immediately continued to build a new business, NeXT Inc., which involved developing and selling computers for education and business purposes. While building the NeXT line, Jobs also invested in a newly spun-off graphics department from Lucasfilm, Pixar Animation Studios, ultimately becoming the company's Chief Executive Officer (CEO). With the help of Jobs and other Pixar leaders, including Ed Catmull, Alvy Ray Smith, and John Lasseter, Pixar Animation Studios became a renowned, leading computer-animation company.

Apple bought NeXT in 1996 and eventually reinstated Jobs as Apple's CEO. Jobs's NeXT operating system became the starting point in developing Apple's 
Macintosh operating system; this paved the way to success through the progressive development and strengthening of Apple software and hardware. Jobs's unrelenting tenacity and perfectionism pushed the company into becoming a leading designer and distributor of consumer-friendly digital devices, providing not only a sleek and stylish product but also a powerful, fine-tuned, complex system software built on the premise of consumer-level functionality and productivity.

Reflecting on Steve Jobs, the man, conjures up a number of conflicting ideas about his personality - perfectionist, brute, visionary, dictator, genius - yet, no one can deny the impact made by Jobs's legacy, Apple Inc., which lives on not only through him having created an entirely new market for consumer-friendly techware and gadgets, but also forever impacting the world's ever-changing notion of digital communication.

Steve Jobs's tenacity did not end with the success of Apple, but effectively revolutionized the world of entrepreneurship and marketing. Small, medium, and large companies zealously commit to finding the key to how Jobs was able to push his company to such great success. What did he do to become the legend he is now? Was it his network with other smart icons like Steve Wozniak and Apple designer Jonathan Ive? Was it his visionary mindset? His genius? Was it simply a matter of efficient business planning and execution? Or perhaps it was his controversial disregard for social and business norms that frequently left employees and suppliers affronted and bewildered? Jobs's style of leadership was not in line with any technique based on nurturing and encouraging employees. However, his method of command and leadership has caused a curious stir in the ideals of how successful companies should be led. Some managers use a critical, direct management of employees, while others continue to uphold a more supportive business culture.

Like him or not, no one can ignore the impact Steve Jobs has had on the technology industry and in the ever-changing realm of digital communication. The world will forever be impacted by Apple's products like the iPod, the Mac computer, the iPhone, and the iPad, which was one of Jobs's last products before his death in 2011. And whether critics portray him personally as god or devil, Steve Jobs will forever be known as the man who built Apple into a cultural symbol to be embraced by the world for years to come.

Sources: Based on Branson (2013); Hisrich (2014); and Isaacson (2011).

\subsection{INTRODUCTION}

This chapter discusses the importance of entrepreneurial marketing for a new or growing company. The concepts of entrepreneurship and marketing are explained, followed by a discussion of their interface. Then, the concept of entrepreneurial marketing and the differences and similarities of traditional and entrepreneurial marketing are presented. The chapter concludes with an introduction to the 4Ps of product, price, place (distribution), and promotion; 4Cs (consumer needs, consumer cost, convenience, and communication); 4Vs (validity, value, venue, and vogue); 
4As (acceptability, affordability, accessibility, and awareness) and 4Os (objects, objectives, organization, and operations) of the marketing mix.

\subsection{MARKETING DEFINITIONS}

Marketing is present in every economic and/or social activity and entity, including company, government, NGOs, political parties, education, tourism, sport, arts, and health. One of its most misunderstood and misinterpreted aspects is marketing research (see Hisrich and Ramadani, 2017; Kerin, Hartley and Rudelius, 2015; Kotler and Armstrong, 2016; Kotler and Keller, 2012). The term "marketing" means different things to different individuals. Some people view it as advertising, some as selling, and others as trading. Advertising, selling, and/or trading are only aspects of marketing; they do not reflect the entire concept of marketing. Marketing needs to be viewed as a much broader concept.

There are several different definitions of marketing. Generally speaking, marketing is a bridge that connects companies and consumers (Veseli, Ramadani and Rexhepi, 2010). Kotler and Armstrong (2016, p. 29) define marketing "as the process by which companies create value for customers and build strong customer relationships in order to capture value from customers in return." The American Marketing Association (2013) has the following definition: "Marketing is the activity, set of institutions, and processes for creating, communicating, delivering, and exchanging offerings that have value for customers, clients, partners, and society at large." Hisrich (2000, p. 3) defines marketing as "the process by which the decisions are made in a totally interrelated changing business environment on all the activities that facilitate exchange in order that the targeted group of customers is satisfied, and the defined objectives are accomplished." According to Pride, Hughes and Kapoor (2014, p. 289), "marketing consists of individual and organizational activities that facilitate and expedite satisfying exchange relationships in a dynamic environment through the creation, distribution, promotion and pricing of goods, services and ideas." Ries and Trout (2006) describe marketing as a war between companies to attract and control consumers - a war that never ends. For US ad agency executive and author Jay Conrad Levinson, "marketing is not an event, but a process. It has a beginning, a middle, but never an end, for it is a process. You improve it, perfect it, change it, even pause it. But you never stop it completely." In this book, marketing is defined and viewed as a process that, through market research, identifies the consumers' needs, desires, and demands, and that, through pricing, distributing, and promoting products or services, satisfies customers and achieves the objectives of 
the organization (Hisrich and Ramadani, 2017). Each of the aspects of marketing are discussed in the following paragraphs:

Needs, wants and demands Identifying the consumers' needs is one of the primary tasks of marketing. Usually, the terms need, desire, and demand are used interchangeably. A need is something elementary that one has to fulfill to survive - one needs food, water, air, clothing, and shelter to survive; one also needs rest, education, and entertainment. A need becomes a want when it is connected to a specific product/service. For instance, when someone needs food, but requires a specific food, such as hamburger, pizza, or spaghetti, then the need is transformed into a want. A demand is a specific want and is supported by the ability to buy it. Someone may want to have a luxury yacht or big house with swimming pools, but few can afford to purchase them. Accordingly, if someone is not able to buy a product or service to satisfy his or her need or desire, then it is not treated as demand or a possible target market.

Products/services As the needs, wants, and demands are identified in the market, then the entrepreneur needs to decide what to offer (product/ service) to meet them and accomplish the objectives of the organization. If the offered products/services do not satisfy any consumer's need or desire, this organization is not appropriately marketing.

Information Informing consumers about the organization's products/ services is an important aspect of marketing. Consumers need to know what a respective organization provides and offers the market. As the organization informs the consumers about its products/services, it needs to convince them to buy or consume them.

Exchange As the particular product is being produced and consumers are being informed, the entrepreneur thinks about the ways the product or service can be delivered to the consumer, such as through direct channels or through wholesalers, retailers, and agents. For the exchange process to be realized, several conditions need to be met (Kotler and Keller, 2012):

- At least two parties exist.

- Each party should possess something that is valuable to the other party.

- Each party should communicate and offer something.

- Each party should be able to decide on whether to accept or reject the offer. 
- Each party should trust that the agreement is good and reasonable for both parties.

Market The place where the products/services are exchanged for usually money is known as a market. The market is the place where entrepreneurs and consumers meet each other. The development of the Internet, where almost all transactions are conducted online, added a digital market to the physical market. Companies cannot successfully satisfy the needs and desires of all consumers, therefore companies need to be focused on a group of consumers who can be differentiated. This process is called market segmentation.

Competition A company does not exist and act alone in the market. Companies that provide (or can provide) the same, similar, or substitute products/services are known as competitors. Companies should craft appropriate strategies to compete successfully with their competitors and obtain more customers.

Environment The environment includes all the factors, external and internal, that directly and indirectly influence the activity of a company. The environment is both macro and micro in nature. The macro-environment includes demographic, economic, political, technological, legal, and sociocultural factors; the micro-environment includes the company, suppliers, intermediaries, consumers, and competition.

\subsection{ENTREPRENEURSHIP DEFINITIONS}

Although the research on and interest in entrepreneurship has increased significantly over the last two decades, several questions still remain: Who is an entrepreneur and why is he or she different from other businesspeople? What is entrepreneurship? What is corporate entrepreneurship? What is social entrepreneurship? What is the entrepreneurial process? These frequently asked questions reflect the increased national and international interest by individuals, groups, academics, students, and government officials in entrepreneurs and entrepreneurship. ${ }^{2}$ This increased interest is to be expected considering that entrepreneurs' creative ideas, the ability to bring innovations to the market, and the ability to take risks are changing people's lives (Ramadani and Schneider, 2013). Today, numerous young and older entrepreneurs around the world launch new ventures. These new ventures create a life for them and their families, create new jobs, and contribute to the overall economic development of the countries involved. 
Regardless of the numerous attempts to obtain a generally accepted definition of entrepreneurship, so far this has not been achieved. Peter Kilby (1971) compared the search for the definition of entrepreneurship with Winnie-the-Pooh's search for the Heffalump in A.A. Milne's famous children's book from 1926. In this story, shown in the box below, entrepreneurship is seen as a great animal that is hunted by many individuals with different traps, but none has been able to capture it so far - all claim to have seen it, agree that it is a huge animal, but disagree about its particularities.

\section{HUNTING THE “ENTREPRENEURIAL” HEFFALUMP}

One day when Christopher Robin and Winnie-the-Pooh and Piglet were all talking together, Christopher Robin finished the mouthful he was eating and said carelessly:

"I saw a Heffalump today, Piglet."

"What was it doing?" asked Piglet.

"Just lumping along," said Christopher Robin. "I don't think it saw me."

"I saw one once," said Piglet. "At least I think I did," he said. "Only perhaps it wasn't."

"So did I," said Pooh, wondering what a Heffalump was like.

"You don't often see them," said Christopher Robin carelessly.

"Not now," said Piglet.

"Not at this time of year," said Pooh.

Then they all talked about something else, until it was time for Pooh and Piglet to go home together.

Source: From A.A. Milne's Winnie-the-Pooh, 1926 (Chapter V).

Entrepreneurship as a word derived from the French entreprendre (to undertake), which, literally translated, means "between-taker" or "gobetween." Richard Cantillon, the sixteenth/seventeenth-century IrishFrench economist, used this word for the first time in his book Essaie sur la Nature du Commerce en Général, which was published in 1755, 20 years after his death. He described the entrepreneur as a risk-taker, comparing them with the farmer who pays the workers and the landowners a certain price, to produce and sell products at an uncertain price in the future, therefore operating at a risk (Hisrich, Peters and Shepherd, 2017). An early example of an entrepreneur as a go-between is Marco Polo, who established 
trade routes to the Far East. As a go-between, Marco Polo would sign a contract with a money person (the forerunner of today's private investor or venture capitalist) to sell the goods. A common contract during this time provided a loan to the merchant-adventurer with about 22 percent interest including insurance. The capitalist was a passive risk-bearer and the merchant-adventurer took the active role in trading, bearing all the physical and emotional risks. When the merchant-adventurer successfully sold the goods and completed the trip, the profits were divided, with the capital provider taking the most - up to 75 percent - while the merchantadventurer settled for the remaining 25 percent.

In the Middle Ages, the term "entrepreneur" was used to describe both an actor and a person who managed large production projects, where this person did not take any risks but merely managed the project using the resources provided, usually by the government of the country. The cleric was considered a typical entrepreneur in the Middle Ages, who oversaw great architectural works, such as castles and fortifications, public buildings, abbeys, and cathedrals.

In the eighteenth century, as Cantillon introduced the theory of entrepreneurship into the literature, the people who provided capital (money providers) were differentiated from those who needed capital (entrepreneurs). This reflected the industrialization occurring throughout the world. Many of the inventions developed during this time were reactions to the changing world, such as the inventions of Eli Whitney and Thomas Edison, who were developing new technologies and were unable to finance their inventions themselves. Whereas Whitney financed his cotton gin with expropriated British Crown property, Edison raised capital from private sources to develop and experiment in the fields of electricity and chemistry. Both Edison and Whitney were capital users (entrepreneurs), not providers (venture capitalists).

In the late nineteenth and early twentieth centuries, in most cases, entrepreneurs were not distinguished from managers (Ely and Hess, 1937, p. 488):

Briefly stated, the entrepreneur organizes and operates an enterprise for personal gain. He pays current prices for the materials consumed in the business, for the use of the land, for the personal services he employs and for the capital he requires. He contributes his own initiative, skill and ingenuity in planning, organizing and administering the enterprise. He also assumes the chance of loss and gain consequent to unforeseen and uncontrollable circumstances. The net residue of the annual receipts of the enterprise after all costs have been paid, he retains for himself.

Andrew Carnegie is a good example of this period and this definition. He adapted and developed new technology in the creation of products 
for economic vitality. From a poor Scottish family, Carnegie made the American steel industry one of the wonders of the industrial world, primarily through his unremitting competitiveness rather than his inventiveness or creativity.

In the middle of the twentieth century, entrepreneurs were seen as innovators. Astonishing contributions to this idea were made by Joseph Alois Schumpeter, who viewed the entrepreneur as a person who provides a new product/service in the market, a new, usually practically untested production method, a new source of raw materials, or as a person who opens up new markets. In this regard, Schumpeter said (1952, p. 72):

The function of the entrepreneur is to reform or revolutionize the pattern of production by exploiting an invention or, more generally, an untried technological method of producing a new commodity or producing an old one in a new way, opening a new source of supply of materials or a new outlet for products, by organizing a new industry.

The concept of innovation and newness is an integral part of entrepreneurship and the act of introducing something new is one of the most difficult tasks for the entrepreneur. It takes the ability not only to create and conceptualize but also to understand all the forces at work in the environment. Edward Harriman, who reorganized the Lake Ontario Southern Railroad through the Northern Pacific Trust, and John Pierpont Morgan, who developed a large banking house by reorganizing and financing the nation's industries, are examples of entrepreneurs fitting this definition. These organizational innovations are frequently as difficult to develop successfully as the more traditional technological innovations (transistors, computers, lasers) that are usually associated with being an entrepreneur.

The concept of an entrepreneur varies depending on the perspective from which it is observed. To an economist, an entrepreneur is one who combines resources, labor, vision, materials, and other assets to increase product/ service value and introduce and implement change, innovation, and a new order. To a psychologist, such a person is typically driven by certain forces the need to attain something, to experiment, to accomplish, or perhaps to escape authority. To one businessperson, an entrepreneur may appear as a threat, an aggressive competitor; to another, the same entrepreneur may be an ally, a supplier, a customer, or a creator of wealth. The effective entrepreneurial manager finds better ways to utilize resources, reduce waste, and produce jobs for willing candidates (Hisrich and Ramadani, 2017).

Even though each of these descriptions views entrepreneurs from a different perspective, they contain similar notions such as newness, organizing, creating, wealth, and risk-taking. Generally, entrepreneurship is the process of "creating something new with value by devoting 
the necessary time and effort, assuming the accompanying financial, psychic and social risks, and receiving the resulting rewards of monetary, personal satisfaction and independence" (Hisrich and Ramadani, 2017, p. 5). This definition stresses four basic aspects of entrepreneurship. First, entrepreneurship involves creating - creating something new of value. The creation must have value to the entrepreneur and to the customer. Second, entrepreneurship requires time and effort. Only those going through the entrepreneurial process truly appreciate the significant amount of time and effort it takes to create something new and make it operational. Assuming the necessary risks is the third aspect of entrepreneurship. These risks take a variety of specific forms but are in financial, psychological, and social areas. The final part of the definition involves the rewards of being an entrepreneur. The most important of these rewards is independence, followed by personal satisfaction and profit in for-profit organizations.

\subsection{IMPORTANCE OF THE ENTREPRENEURSHIP AND MARKETING INTERFACE}

The entrepreneurship and marketing interface is an important issue for several reasons (Hisrich, 1992). First, many studies on entrepreneurs and entrepreneurship around the world reveal that the greatest problem areas are marketing and finance. Finance problems are related to obtaining capital to start a new business, financing growth, cash flow management and financial control, where obtaining the initial capital needed to build a prototype or start initial production seems to be the most difficult. Marketing problems often reflect the lack of a marketing plan, inaccurate determination of market size, and unreliable sales forecasts. Sound marketing is a necessary component for developing a new product/service for the market, as well as successfully selling, nurturing, and growing the company.

Second, many entrepreneurs have a limited knowledge about marketing and believe that all they need is an innovative product/service and that all consumers will buy this product/service. This misguided belief is often caused by the so-called "bag mentality" of entrepreneurs, where entrepreneurs are so afraid that someone will steal their idea, they put it in a "bag" and do not obtain any market feedback. Without market feedback, entrepreneurs may provide unsuccessful products and still expect unrealistic sales. To be successful, entrepreneurs need to have information to determine the appropriate market segment, price, distribution, and communication.

Third, many entrepreneurs can be bad marketing managers. Very often, entrepreneurs underestimate the time and effort needed to accomplish 
a certain marketing task and overestimate the sales that will result. This results in poor marketing plans. A poor marketing plan may even cause the loss of the business when the entrepreneur is tied to a specific sales objective and performance by the funding source.

Entrepreneurship and marketing also have many similarities. First, the consumer is a focal point of both concepts, which means that the two should be based on consumer orientation. Second, both entrepreneurship and marketing have a "deal" mentality - the deal is a central factor in conceiving and developing a new business for the entrepreneur and closing a sale for the marketer. Finally, both concepts involve the development of distinctive competence; both are affected by environmental turbulence; and both are all-encompassing - entrepreneurship in terms of developing an entirely new business and marketing in terms of its models.

\subsection{ENTREPRENEURIAL MARKETING CONCEPTS}

Interest in entrepreneurial marketing as a new field of study began in 1982, when the International Council for Small Business and the American Marketing Association jointly organized a conference. In 1985, Gerald Hills published the first empirical study of the marketing and entrepreneurship interface in Frontiers of Entrepreneurship Research. In 1987, Michael Morris and Gordon Paul published "The relationship between entrepreneurship and marketing in established firms" in the Journal of Business Venturing and moved entrepreneurial marketing research into higher academic standing. In 1992, Robert Hisrich published "The need for marketing in entrepreneurship" in the Journal of Consumer Marketing. In 1999, the Journal of Research in Marketing and Entrepreneurship was launched as the first scientific journal that handled issues of entrepreneurial marketing. By the end of 2018, there will be 18 volumes and 36 issues of this journal. Entrepreneurial marketing's importance further increased in 2010 when researchers at the Charleston Summit redefined the entrepreneurship and marketing interface and offered a conceptual framework for future research (Hills, Hultman and Miles, 2008; Ioniță, 2012).

One significant unanswered question remains: how does entrepreneurial marketing differ from traditional marketing? Some of the differences between traditional and entrepreneurial marketing are summarized along four dimensions: business orientation, collecting information, tactical perspective, and strategic perspective (Stokes, 2000). Table 1.1 also presents some of the main differences between entrepreneurial and traditional marketing. In terms of business orientation, entrepreneurial marketing is oriented towards entrepreneurs and innovations, while traditional marketing is more customer 


\section{Table 1.1 Differences between traditional marketing and entrepreneurial marketing}

\begin{tabular}{|c|c|}
\hline Traditional Marketing & Entrepreneurial Marketing \\
\hline $\begin{array}{l}\text { An essentially reactive stance with } \\
\text { respect to the external environment }\end{array}$ & $\begin{array}{l}\text { The firm attempts to influence or } \\
\text { redefine aspects of the external } \\
\text { environment }\end{array}$ \\
\hline $\begin{array}{l}\text { Marketing strives to follow customers, } \\
\text { serving existing markets }\end{array}$ & $\begin{array}{l}\text { Marketing strives to lead customers, } \\
\text { creating new markets }\end{array}$ \\
\hline $\begin{array}{l}\text { Focal point is efficient management } \\
\text { of the marketing mix }\end{array}$ & $\begin{array}{l}\text { Focal point is new value creation for } \\
\text { the customer through relationships, } \\
\text { alliances, resource management } \\
\text { approaches, and the marketing mix }\end{array}$ \\
\hline Risk is to be minimized & $\begin{array}{l}\text { Risk is necessary and marketing's job is } \\
\text { to manage the firm's risk profile in a } \\
\text { calculated fashion }\end{array}$ \\
\hline $\begin{array}{l}\text { Marketing as an objective, } \\
\text { dispassionate science }\end{array}$ & $\begin{array}{l}\text { While acknowledging the value of } \\
\text { science and learning, recognition is } \\
\text { given to the roles of passion, zeal, and } \\
\text { commitment in successful marketing } \\
\text { programs }\end{array}$ \\
\hline $\begin{array}{l}\text { Reliance on proven formulas and } \\
\text { established rules of thumb }\end{array}$ & $\begin{array}{l}\text { Psychology of challenging commonly } \\
\text { shared assumptions }\end{array}$ \\
\hline $\begin{array}{l}\text { Marketing supports the innovation } \\
\text { efforts of other functional areas } \\
\text { of the firm, most notably R\&D }\end{array}$ & $\begin{array}{l}\text { Marketing is the home of the } \\
\text { entrepreneurial process in the } \\
\text { organization }\end{array}$ \\
\hline Marketing as a functional silo & $\begin{array}{l}\text { Marketing as a cross-disciplinary and } \\
\text { inter-functional pursuit }\end{array}$ \\
\hline $\begin{array}{l}\text { Promotion and customer } \\
\text { communication receive the greatest } \\
\text { amount of attention from marketers }\end{array}$ & $\begin{array}{l}\text { The relative investment or resources in } \\
\text { different areas of the marketing mix } \\
\text { are context specific }\end{array}$ \\
\hline $\begin{array}{l}\text { Scarcity mentality, zero-sum game } \\
\text { perspective on resources }\end{array}$ & $\begin{array}{l}\text { Opportunity is pursued regardless of } \\
\text { resources controlled; philosophy of } \\
\text { resource leveraging is paramount }\end{array}$ \\
\hline Heavy dependency on survey research & $\begin{array}{l}\text { Skeptical use of conventional research; } \\
\text { employment of alternative methods } \\
\text { (e.g., lead user research, "backward" } \\
\text { research) }\end{array}$ \\
\hline $\begin{array}{l}\text { Marketing facilitates transactions and } \\
\text { control }\end{array}$ & $\begin{array}{l}\text { Marketing facilitates speed, change, } \\
\text { adaptability, agility }\end{array}$ \\
\hline
\end{tabular}

Source: Based on Morris, Schindehutte and La Forge (2002). 
oriented. According to traditional marketing, the entrepreneur should initially identify and assess market needs and then develop a new product/ service; according to entrepreneurial marketing, the entrepreneur should generate initially an (unique) idea, convert that idea to a new product/service, and then find a market. From the second dimension, collecting information from the market, entrepreneurial marketers usually use informal methods such as personal observation or personal networks/contacts. They usually do not use formal research methods due to their higher costs. From the tactical perspective, entrepreneurial marketers use an interactive marketing approach, which is based on personal and direct contacts with consumers. For entrepreneurial marketers, word-of-mouth and references from consumers are very important. From a strategic perspective, entrepreneurial marketing uses a bottom-up approach, while traditional marketing uses a top-down approach. The top-down approach requires a clearly defined order of activities, such as segmentation, targeting, and then positioning. The entrepreneurial bottom-up approach initially requires identification of an opportunity, which needs to be tested. The company satisfies the needs and desires of a limited number of consumers in the beginning and then expands these sales through direct contact with consumers. Some of the several definitions of entrepreneurial marketing are presented in Table 1.2.

One of the most widely used definitions is provided by Morris et al. (2002, p. 5), who defined entrepreneurial marketing as: "proactive identification and exploitation of opportunities for acquiring and retaining profitable customers through innovative approaches to risk management, resource leveraging and value creation." This definition incorporates elements of both concepts: entrepreneurship (proactiveness, risk-taking, opportunity, and innovation) and marketing (customer focus, resource leveraging, and value creation).

The concept of entrepreneurial marketing consists of six elements (Morris et al., 2002):

- Customer intensity. This aspect focuses on the enthusiasm, passion, zeal, and belief in marketing that help to make the company successful. It is believed that a customer-intensity element strengthens the core values of the company and the passion for the customer.

- Continuous innovation. An entrepreneurial company should continuously generate creative ideas and convert them into new or adapted products/services or processes.

- Strategic flexibility. An entrepreneurial company should show a willingness to continuously review and adjust its strategies, action plans, methods of resource allocation, structure, culture, and management systems. 
Table 1.2 Definitions/explanations of entrepreneurial marketing

\begin{tabular}{|c|c|}
\hline Author (s) & Definition/Explanation \\
\hline Stokes $(2000)$ & $\begin{array}{l}\text { The entrepreneurial marketing concept is focused on } \\
\text { innovations and the development of ideas in line with an } \\
\text { intuitive understanding of market needs }\end{array}$ \\
\hline Collinson and & Entrepreneurial marketing is characterized by a \\
\hline Shaw (2001) & $\begin{array}{l}\text { responsiveness to the marketplace and a seemingly intuitive } \\
\text { ability to anticipate changes in customer demands }\end{array}$ \\
\hline Morris, & Entrepreneurial marketing is proactive identification \\
\hline Schindehutte and & and exploitation of opportunities for acquiring and \\
\hline LaForge (2002) & $\begin{array}{l}\text { retaining profitable customers through innovative } \\
\text { approaches to risk management, resource leveraging, and } \\
\text { value creation }\end{array}$ \\
\hline Bäckbrö and & Entrepreneurial marketing is the overlap between \\
\hline Nyström (2006) & $\begin{array}{l}\text { entrepreneurship and marketing. It is the behavior by } \\
\text { any individual and/or organization to establish and } \\
\text { promote market ideas while developing new ones to create } \\
\text { value }\end{array}$ \\
\hline Miles and & Firms adopting entrepreneurial marketing processes \\
\hline Darroch (2006) & $\begin{array}{l}\text { (EMPs) will engage in marketing processes that emphasize } \\
\text { opportunity creation and/or discovery, evaluation, and } \\
\text { exploitation }\end{array}$ \\
\hline $\begin{array}{l}\text { Kraus, Harms } \\
\text { and Fink (2010) }\end{array}$ & $\begin{array}{l}\text { Entrepreneurial marketing is an organizational function and } \\
\text { a set of processes for creating, communicating, and delivering } \\
\text { value to customers and for managing customer relationships } \\
\text { in ways that benefit the organization and its stakeholders, } \\
\text { and that is characterized by innovativeness, risk-taking, } \\
\text { proactiveness, and may be performed without resources } \\
\text { currently controlled }\end{array}$ \\
\hline Hill et al. (2010) & $\begin{array}{l}\text { Entrepreneurial marketing is a spirit, an orientation, as } \\
\text { well as a process of pursuing opportunities and launching } \\
\text { and growing ventures that create perceived customer } \\
\text { value through relationships, especially by employing } \\
\text { innovativeness, creativity, selling, market immersion, } \\
\text { networking or flexibility }\end{array}$ \\
\hline
\end{tabular}

- Calculated risk-taking. Risk-taking means pursuing new opportunities. Entrepreneurs take calculated risks, but some can be fatal for the future of the company.

- Proactiveness. Entrepreneurs are aware of the importance of the external marketing environment, but they do not take it as a given. They perceive it as a horizon of possibilities. In other words, 
entrepreneurs try to redefine the elements of the external environment to reduce its uncertainty, reduce dependence and vulnerability of the company, and/or modify the environment in which the company operates.

- Resource leverage. Since entrepreneurs' ambitions usually exceed their resources, they are forced to use their resources in the best possible way. They leverage their resources: they use resources for much longer than others have used them in the past; they use resources that others do not view as resources; they use other people's/companies' resources to fulfill their own goals; and they blend one resource with another to create a greater combined value.

\subsection{ELEMENTS OF THE MARKETING MIX}

The main elements of marketing are product, price, place (distribution) and promotion, often described as the 4Ps of marketing. A detailed discussion of each of these marketing mix elements is provided in Chapters 5, 6,7 , and 8 . In the services sector, the $4 \mathrm{P}$ acronym becomes $8 \mathrm{P}$ by adding people, process, presence, and physical evidence. People are one of the main resources of the company - owners, employees or consumers. This element differentiates you and your competitors, your employees and competitors' employees and your consumers and competitors' consumers. Process is the steps of producing and delivering the product/service to the consumers. It includes the ways a certain service is sold and accepted by the consumer. Presence is how your store, warehouse or website look and how the consumers feel when visiting them. Physical evidence is related to the tangible components of the product/service, such as office premises, brochures, or user stories.

According to Lauterborn (1990), the 4Ps correspond to the consumers' 4Cs: consumer needs, consumer cost, convenience, and communication. Consumer needs involves an interaction between the entrepreneur and the consumer. Entrepreneurs should offer a product/service that satisfies the consumers' needs and/or problems. From the consumer's perspective, costs of the product/service should be at a level they perceive as fair and affordable. The product price is not the only element of the consumers' cost; there are also the costs of currency exchange if the product/service is offered in the international market, as well as any delivery costs and time. Convenience means that the entrepreneur should make the product/service available to consumers with minimum effort. Consumers want to purchase the products/services in the easiest way. This is the reason companies are establishing more sales points to attract and reach as many consumers as 

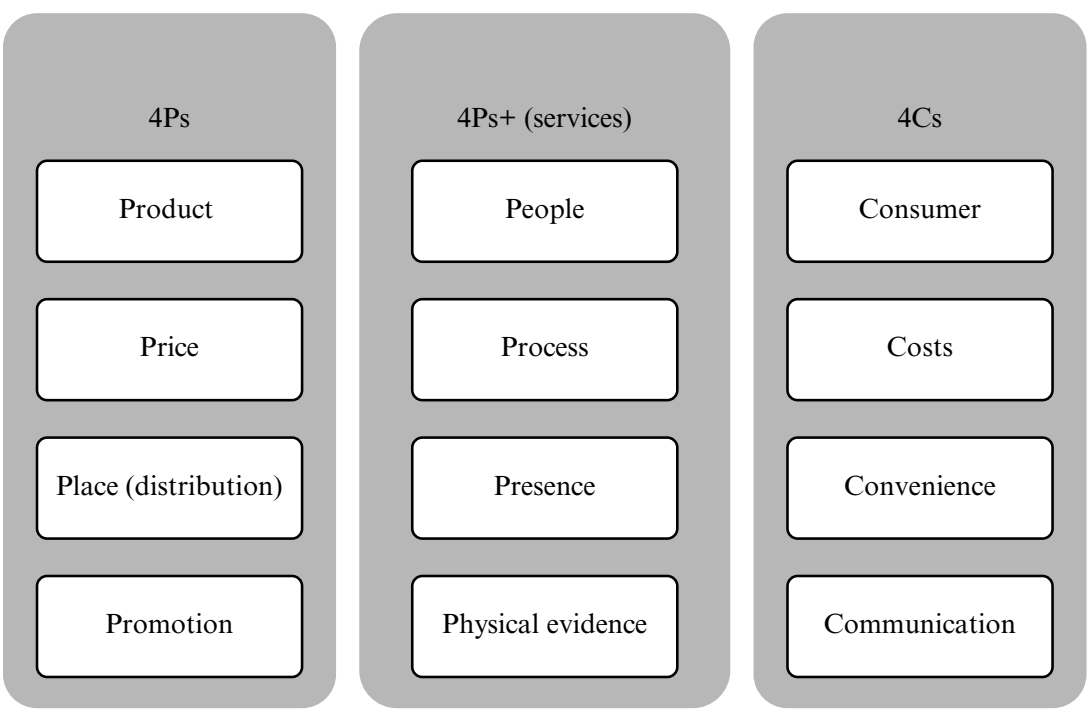

\section{Figure 1.1 The elements of the marketing mix}

possible. Communication is different from promotion. While promotion is a one-way medium, communication is a two-way and interactive medium between entrepreneurs and consumers. While promotion is more about informing the consumers about the company's product/service, communication is more about listening to consumers' needs, desires, and demands (Figure 1.1).

In addition to the $4 \mathrm{Ps}$ and $4 \mathrm{Cs}$, there are also the $4 \mathrm{Vs}$ (validity, value, venue, and vogue), the 4As (acceptability, affordability, accessibility, and awareness), and the 4Os (objects, objectives, organization, and operations) of the marketing mix. These new elements of marketing mix are presented in Table 1.3.

\subsection{SUMMARY}

This chapter has focused on the essentials of marketing, entrepreneurship, and entrepreneurial marketing. Different definitions of and perspectives on these concepts have been provided, as well as similarities and differences between traditional marketing and entrepreneurial marketing. The chapter concluded with a brief discussion of the main marketing mix elements: the 4Ps (product, price, place, and promotion) which will be elaborated on in following chapters, as well as a presentation of the 4Cs (consumer 
Table $1.34 \mathrm{Vs}, 4 \mathrm{As}$, and $4 \mathrm{Os}$ of the marketing mix

\begin{tabular}{|c|c|c|}
\hline $4 \mathrm{Vs}$ & $4 \mathrm{As}$ & $4 \mathrm{Os}$ \\
\hline $\begin{array}{l}\text { Validity } \\
\text { Product/services, } \\
\text { besides being produced } \\
\text { according to consumers' } \\
\text { needs, should be } \\
\text { environmentally friendly, } \\
\text { safe, and socially secure }\end{array}$ & $\begin{array}{l}\text { Acceptability } \\
\text { Product/services, besides } \\
\text { being attractive and } \\
\text { fashionable, should } \\
\text { be socially and legally } \\
\text { acceptable by consumers }\end{array}$ & $\begin{array}{l}\text { Objects } \\
\text { Refer to the way the } \\
\text { product is produced } \\
\text { or service is offered to } \\
\text { consumers; product/ } \\
\text { service quality is also } \\
\text { included }\end{array}$ \\
\hline $\begin{array}{l}\text { Value } \\
\text { Products/services should } \\
\text { provide value for money } \\
\text { as living standards and } \\
\text { quality of life are rising }\end{array}$ & $\begin{array}{l}\text { Affordability } \\
\text { Products/services should } \\
\text { be offered in the market } \\
\text { at an affordable price for } \\
\text { consumers }\end{array}$ & $\begin{array}{l}\text { Objectives } \\
\text { Refers to the revenues } \\
\text { and profits that the } \\
\text { company should generate } \\
\text { and the price that ensures } \\
\text { these revenues and profits }\end{array}$ \\
\hline $\begin{array}{l}\text { Venue } \\
\text { Besides offering products/ } \\
\text { services at more sales } \\
\text { points, entrepreneurs } \\
\text { should consider } \\
\text { additional services - for } \\
\text { example, home delivery }\end{array}$ & $\begin{array}{l}\text { Accessibility } \\
\text { Products/services should } \\
\text { be easily accessible by } \\
\text { consumers, especially by } \\
\text { those with disabilities }\end{array}$ & $\begin{array}{l}\text { Organization } \\
\text { Refers to the methods } \\
\text { and ways of selling and } \\
\text { distributing products/ } \\
\text { services }\end{array}$ \\
\hline $\begin{array}{l}\text { Vogue } \\
\text { Entrepreneurs, besides } \\
\text { communicating the } \\
\text { message to consumers, } \\
\text { should ensure that it } \\
\text { is well accepted by } \\
\text { consumers }\end{array}$ & $\begin{array}{l}\text { Awareness } \\
\text { As many consumers as } \\
\text { possible should be made } \\
\text { aware of products/services }\end{array}$ & $\begin{array}{l}\text { Operations } \\
\text { Refer to the types of } \\
\text { promotional activities of } \\
\text { products/services }\end{array}$ \\
\hline
\end{tabular}

needs, consumer cost, convenience, and communication), 4Vs (validity, value, venue, and vogue), 4As (acceptability, affordability, accessibility, and awareness) and 4Os (objects, objectives, organization, and operations) of the marketing mix. 


\subsection{CASE STUDY: VERSARE, INC.}

\section{Introduction}

On a cold winter morning in 2006, Jeff Ryan sat in his office steaming over the fax he had just received from his long-time distribution partner. This could easily be the last straw for the company, as what choice did he have since this partner was responsible for the sales and distribution of over 95 percent of their product? The fax had come on the heels of a highly charged discussion with this distributor just two days earlier, which had been tense but ended with the distributor assuring Jeff that they would continue their exclusive arrangement with Versare. At the meeting, Jeff aired his concerns about the distributor's lack of interest in the business, the cost increases for Versare, and the distributor's poor receiving and order-taking processes, which cause expensive and unnecessary extra work on wall bed installations. As Jeff walked out of the meeting, though, he was assured by the distributor's president that they were maintaining the exclusive arrangement. "We give you our word. Everything goes through you," he assured Jeff.

So, despite the tensions, he felt good about the agreement that had been reached two days earlier. But this fax changed everything. Sent to Versare by mistake, the fax was intended for a competitor, and it included a large order for the same product that the distributor had promised would come only from Versare. Jeff quickly realized that the distributor's assurances of two days earlier had been a lie. In his head, he could already hear the president saying, "It's just business you understand." While he did understand, he also knew that this relationship accounted for nearly all his company's revenues. In hindsight, this may not have been smart, but in the early days it had been the only way to get the company's product to the customers. The alternative of direct sales, or a patchwork dealer network, was simply not a viable business model in 1998 when the company was founded. All this begged the question of what to do next. Could they afford to continue the relationship with the distributor? Could they afford not to continue the relationship? What were their alternatives?

\section{Versare's History}

Robert Jantschek and Jeff Ryan founded Versare in 1998. The two had met while working at a manufacturer and distributor of mobile folding and rolling, space-efficient products. They left the company to start their own venture in 1998: "We left on pretty good terms. You know, we look back at it and we kind of joked that it would have been smarter to wait a year and develop everything and start the company on somebody else's dime. But Robert and I couldn't do that," said Jeff.

Their first location was shared with a custom cabinetry company that did very high-end cabinetry work for upscale offices and homes. As Jeff explained, "We bunked with them because I had had a relationship with the owner. He used to do work for me when I was at my previous life. The equipment he had we needed to build our stuff. So, it was a good marriage."

The first product they developed was a portable room partition that they believed had significant competitive advantages over other product offerings in the market. While in the same general market as their previous employer, the product did not compete directly with any of its offerings. Versare manufactured the entire partition 
in-house, but distribution was a challenge. They had a manufacturing arm, a marketing arm, and a distribution arm. Unfortunately, the distribution arm could not sign up any dealers. And they did not have the resources to build it, "buy a van and put a guy in a territory." The company was saved in July 1998 when Jeff secured Hufcore as a distributor. Hufcore had a national dealer network that could sell their initial product. At approximately the same time, Jeff began conversations with their previous employer.

\section{The Product and the Market}

Portable partitions are movable walls - used mainly by institutions such as schools, churches, hotels, and conference centers to divide large rooms into smaller, more intimate spaces. They are part of a larger category of portable products used by institutions to add flexibility to their larger rooms, similar to portable dance floors, choral risers, portable stages, and folding tables. These products generally come under North American Industry Classification System (NAICS) Code 337215 showcases, partitions, shelving and lockers. In 2005, the 1789 companies in this industry generated approximately $\$ 9$ billion in sales and employed 54000 in the USA. ${ }^{\text {a }}$

These products are generally sold through a distribution network that includes local dealers and large distributors and catalog houses. Delivery times are generally four to six weeks to the end customer, with the products being shipped via local freight services to the loading docks of the institutional purchaser. Freight costs can run from $\$ 300-400$ per partition. Dealers generally do not hold significant inventory, but place orders as needed with the distributors or manufacturers. Delivered price to the customer, including shipping, has averaged at about $\$ 850$ for a basic partition.

\section{The Distributor Relationship}

The combination of Robert's design skills, the equipment they had purchased and cobbled together, and access to their office mate's millwork equipment provided them with a wide range of skills and potential work. The problems in attracting a dealer network had spurred the company on to begin looking for contract work and anything else they could do to generate revenues. This led to a conversation with the president of their former employer: As Jeff said: "We had all these extra things that we could do, but I started a conversation with the president of our former employer about something else. During the meeting I said, 'Yeah, we've got all this millwork,' and he said, 'Well, we're really having trouble with the guys that do our case goods for our wall bed system. Would you be interested in it?' So I said, 'Sure,' and he handed me an order for $\$ 162000$."

The distributor is a long-standing company located in Minnesota. In 2007, it employed 350 people with sales of approximately $\$ 25$ million. ${ }^{b}$ The distributor manufactures and distributes a range of portable products for institutional users (hospitals, hotels, schools, churches) such as folding tables, choir risers, portable dance floors, luggage carts, and so on. It is a leader in the industry and a private family-owned company. In both culture and operations it is a very traditional, conservative mid-sized Midwestern company, stable and prosperous while achieving modest annual growth. It had not yet embraced the Internet in the late 1990s. 
It was still a brick-and-mortar, suitcase, car, van, and printed literature company with no plans to change. It was positioned as a high-price provider of high-quality, fully featured, very reliable products in its market. According to Jeff Ryan, its philosophy was, "We're 30 percent higher and we better prove we're worth it."

By January 1999, Versare had become the primary supplier of the wood casing for the distributor's wall beds, and also assembled the beds the distributor was selling to the hospitality industry. Sales of wall beds quickly became a $\$ 500000$ business for Versare. In November of 1999, the distributor approached them with an offer to manufacture its portable wall partition under the distributor's name and branded as "The Insta-Wall." They priced the Insta-Wall at \$1099 including shipping: "We had no sales force. We were struggling to get it sold. We had one OEM [original equipment manufacturer] out of Janesville that was selling it, but they were only doing $\$ 400000$ a year. So, you combo the two and we were under a million. We wanted to get bigger than that and we thought that that would be the way to do it," said Jeff.

In November 1999, Versare entered into an OEM contract with the distributor for its portable partition, a contract that in hindsight may not have been in Versare's best interests. "I look at the contract today and realized what they were doing. In fact, we knew it back then too. It basically says, 'We will sell this OEM, but, oh, by the way, you cannot manufacture any other products that are similar to any of our other products,"' said Jeff.

The contract was for 18 months and automatically renewed unless one party informed the other that they were terminating the contract prior to the renewal. Once notified of the intent to terminate, the contract remained in force for 18 months. Once the contract was signed, sales increased substantially for the portable partition. The distributor's dealer network began moving the product throughout the country. In April of 2000, the distributor came to Jeff and demanded that they no longer sell directly to Hufcore. Jeff said: "They came to us and said, 'Oh, you can't sell to Hufcore anymore. You have to sell to us and we'll sell to Hufcore'. . .you can imagine what happened to our sales through Hufcore. Sales went to zero."

Versare's revenues grew from $\$ 250000$ in 1998 to over $\$ 1$ million in 2000 and its work force had expanded from the two partners to 13 employees. But after the September 11, 2001 terrorist attacks, the orders stopped. Within six months they were back down to themselves and a skeleton crew, and 100 percent dependent on the distributor for their revenues. The following year, 2002, was bleak.

The relationship with the distributor was supportive but also contentious. Jeff explained how the relationship worked in the wall beds segment: "We kind of filled in the gap. The customer would ask us for details that the distributor should have already provided. . . We'd fill in the gap. . .step up for the customer, and we'd make it happen."

The distributor supported Versare in many ways, including providing partial payment in advance for some big orders, paying promptly in 30 days, and investing $\$ 75000$ in Versare's inventory to allow Versare to maintain the inventory on hand to meet the two-week delivery time the distributor demanded. On the other hand, the distributor made a lot of demands for features and product changes. As Robert explained: "Once they came in and they were OEMing the product they started to sell it, but then there was always something. No matter what we did there was always 
'Oh, we want you to change this' and we started chasing our tail a lot. They never had anybody who had embraced our product. It was always, 'Oh, by the way,' or 'Oh, I guess we do have this.' So, when you asked them, they'd make the sale. So you have all these different dealers and all these different reps out there getting that fall-off-the-truck sale, but every time they got that sale it was like, 'Oh, by the way, but if it did this. ..' We heard that a million times. So, Jeff would say, 'Gosh, I'm seeing sales volume drop,' and they'd come back and say, 'Well, if it only did this, we could assure you this.' So by the end of our relationship we had probably the biggest Rube Goldberg devices ${ }^{c}$ you could ever imagine because we always gave them what they asked."

At one point the distributor demanded that a rubber gasket be developed for between the folding pieces of the partition to protect children's fingers. Versare had to spend $\$ 10000$ on a special piece of equipment to create the gasket. While the additional features added to the cost, the distributor refused to raise the price to the customer, or the price they paid Versare. In fact, Versare was contractually forbidden from raising prices of the product to the distributor during the year; prices could only be adjusted at the start of the year, and, once set, remained in place for the entire year.

The distributor prohibited Versare from direct contact with customers, yet no one at the distributor had direct responsibility for the product. No one took the time to assess the market and what the market really wanted, and Versare could not because it never had the chance to talk to the customer. . .the distributor was its customer. As Robert noted, "So if Joe the sales person out in the south territory said it needs to do this, it needed to do that. Nobody embraced the product at the company and said, 'No, no, no, no. Here are our features and benefits and here's what we need'."

The relationship also included co-marketing between Versare and the distributor at trade shows. The distributor would purchase a large booth at the key shows and place Versare's portable partition on the edge somewhere, while highlighting their own products in the central spaces. None of the distributor's sales staff would directly answer questions, show or sell Versare's products. This led to Jeff traveling to the shows at Versare's expense and representing the product in the booth, following up on leads and then handing them over to the distributor and their dealer network.

\section{The School Specialty Catalog}

In late 2002, the distributor approached Versare with an opportunity to get into the School Specialty Catalog, the leading provider of instructional solutions, basic school supplies and equipment to K-12 schools. As Jeff describes it, "They're out of Appleton, Wisconsin and they own the K-12 market. If you buy something in the $\mathrm{K}-12$ you're buying it out of this catalog." However, to get into the catalog, the distributor demanded that they reduce their price by 25 percent to meet the price of a competitive product already listed in the catalog. Versare agreed to lower their price to the distributor by 25 percent for catalog sales. The distributor than came back and said, "Oh, by the way, since you gave us 25 percent less for these guys, you have to now do it for every product you sell, otherwise we're out." In the end, Versare took a 25 percent price cut on all its partition products. The product was featured in the 2003 School Specialty Catalog. Sales rebounded and 2003 was a 
record year for revenues, at $\$ 1.3$ million, but profits did not follow suit. Versare reduced their price by 25 percent; sales of partitions increased to about $\$ 750000$ on double the number of units. To quote Robert, "We worked a lot harder and made slightly less." Versare had to nearly double its infrastructure to support the growth, even though revenues grew substantially slower. Jeff noted "We never had a chance to grow equity. You know, we were always in a survival mode because we got squeezed, squeezed, squeezed and we were growing, growing, growing, but our margins were shrinking, shrinking, shrinking. So we never could put nothing down." More than 95 percent of Versare's revenues still flowed directly through the distributor, with most of their volume for the partitions coming from the School Specialty Catalog.

The distributor did not have any salesperson actually calling on the School Specialty Catalog managing the account. In January of 2004, Jeff had a school meeting with the Edina school board and was asked what he did. They had a brand-new School Specialty Catalog on the table - "I'm looking through it to show them what we do, and I see my competitor but we're not even in the catalog. The catalog had just come out and that's how we found out. The next day I literally threw the catalog down on the president's desk and said, 'What happened?' He had no idea. He was so embarrassed that he did not know that they got thrown out."

In 2004, with their partition dropped from the catalog, sales stagnated, and margins continued to decline as the distributor demanded that additional features be added to the product. By 2005, Versare's profitability had declined to the point that Robert had to take a full-time job at another company.

\section{Robert in China}

Robert's new position was managing several product lines for his new employer. The job required frequent travel to China for extended periods of time to oversee the design and manufacturing of these product lines by Chinese companies. It was there that Robert had an epiphany.

During the first half of 2005, as Robert described it, "You know, I basically took over a few of their product lines. They basically just threw me to the wolves. I had no idea what I was doing. I figured it out and learned how to do business in China." Robert was over there for extended periods of time by himself, leaving him some free time to explore opportunities for Versare. Robert discovered that China presented Versare with "the opportunity to really make a first-class product with a limited budget."

Robert focused on a simplified, streamlined design that removed much of the clutter that the distributor had demanded be added to their products over the years. Shipping had always been a significant challenge for partitions, which required the use of expensive, slow, and unreliable local freight services. Partitions were shipped fully assembled because dealers did not want to do the assembly. The products were designed to be easily assembled. This made the partitions heavy, awkward, and challenging to ship, which also made them easily damaged during shipping. Robert noted that with the new design they could "get shipping costs down to $\$ 40$ a box to any address." The new product, the MP10, was designed to do 90 percent of what the existing portable partitions did but also be easily packaged, shipped, and assembled. Robert also estimated that the new design would require less than half the labor at their plant to complete the assembly. Robert took 
the designs to one of his contacts in China, who offered to develop the mold in two weeks for $\$ 1500$, a process that cost \$15000-20000 in the United States and took over a month. The new design was to be constructed in components that would be manufactured in China, shipped to Minneapolis, and assembled into the finished product. Jeff and Robert agreed to have the mold developed and prototypes created. Proud of their innovation, Versare were convinced it would be well received in the market - if they could get it to the market. They estimated that delivered price for the MP10 would be less than $\$ 600$.

\section{Potential from Online Sales}

New design in hand, Jeff attempted unsuccessfully to get back into the School Specialty Catalog. He attempted to reach an agreement with Staples to sell and distribute their product, again with no success. The distributor was still generating 95 percent of Versare's revenues, split about evenly between partitions and wall beds.

Versare's last option was to become a direct company through online sales. Versare had had a simple informational website, Versare.com, since 2003, but no e-commerce or direct sales occurred. The site attracted very little traffic and was rarely updated or changed. Neither Jeff nor Robert had any significant knowledge of the Internet, or more specifically, e-commerce or Internet marketing. In fact, Versare was not even set up to accept credit card orders. In late 2005, they began researching the Internet and specifically looking at Google. Jeff began reading every article about Google and how they were operating.

\section{The Opportunity}

As Jeff sat in his car after that fateful fax in January of 2006, it was clear to him that they had an opportunity to go direct to the consumer via the Internet, but that it was very risky and uncertain. No institutions were currently purchasing this type of product online, especially expensive products like theirs that cost $\$ 1500$. The distribution and sales channels were well-established and institutionalized. Still, selling online offered several advantages. One was eliminating the costs of the distribution margin, allowing them to capture retail pricing. Another advantage was that Versare's cash flow cycle would shift from a six- to eight-week negative cash flow cycle to a pre-paid positive cash flow. Through their research, Jeff and Robert concluded that they would need to invest at least $\$ 150000$ to develop their e-commerce capabilities and get two containers of the new MP10 manufactured and shipped to them - which at that moment was $\$ 150000$ more than Versare had in January of 2006. In order to get the necessary capital they would need to place second mortgages against their houses. Beyond the basic investment, Versare might also need as much as another $\$ 150000$ to maintain liquidity during any transition, particularly if sales via the distributor declined in response to this move and they were sitting on the $\$ 80000-90000$ in credit card debt that had supported company operations.

The move to direct sales of the MP10 would put the relationship with the distributor at significant risk, jeopardizing nearly $100 \%$ of their revenues, of which only half are from partitions. How should they handle the distributor? Inform them directly of their new offerings? Given their contractual obligations, the distributor 
probably had the ability to block them from selling directly for the remaining 18 months of their contract. If the distributor exercised that option and shifted their orders to other companies, it would bankrupt Versare.

On this cold January day in Minneapolis, Jeff knew he and Robert had to decide whether to stay with the distributor, move to direct sales of their new product via the Internet, or wind Versare down, and return to working for somebody else.

\section{Case study assignments}

Discuss the following questions with your classmates:

1. What should Jeff do about the fax?

2. Has the relationship with the distributor been beneficial to Versare in the past? Was it still beneficial in 2006?

3. Did Jeff and Robert make a mistake in entering the relationship with the distributor? In hindsight, what would you do differently in managing the relationship with the distributor?

4. Should Versare send a termination letter to end the contract?

5. What strategy and business model should Versare pursue moving forward?

Notes:

a. Darnay, A.J. and J.P. Simkin (eds) (2009), Manufacturing \& Distribution USA: Industry Analyses, Statistics and Leading Companies, Vol. 2, 5th edition, Detroit: Gale, pp. 1601-6.

b. Global Duns Market Identifiers, July 29, 2011. Copyright 2007 Dun \& Bradstreet, Inc.

c. Rube Goldberg, cartoonist, sculptor and inventor, is best known for a series of cartoons depicting complicated gadgets that perform simple tasks in convoluted ways.

Source: Adapted from Deeds, D. (2014). "Versare, Inc. -the accidental fax," Entrepreneurship \& Innovation Exchange, June 26.

\subsection{QUESTIONS FOR DISCUSSION}

1. How do you define marketing? Analyze different perspectives.

2. Debate on the main concepts of marketing. Provide examples.

3. How do you define entrepreneurship? Meet some entrepreneurs in your city and discuss this question with them.

4. How do you define entrepreneurial marketing? Why it is different from traditional marketing? Discuss this using examples.

5. Discuss with your classmates the entrepreneurial marketing mix elements.

6. Explain the marketing mix elements. 


\subsection{KEY TERMS}

- Distribution

- Entrepreneurial marketing

- Entrepreneurship

- Marketing
- Marketing mix

- Price

- Product

- Promotion

\section{NOTES}

1. J.C. Levinson's great quotes can be found here: http://www.azquotes.com/author/38572Jay_Conrad_Levinson; accessed April 30, 2018.

2. Portions of this section are adapted from Chapter 1 of Hisrich, R.D. (2014), Advanced Introduction to Entrepreneurship, Cheltenham, UK and Northampton, MA, USA: Edward Elgar Publishing.

\section{REFERENCES}

American Marketing Association(2013), "Marketingdefinition,"accessed August 13, 2017 at https://www.ama.org/AboutAMA/Pages/ Definition-of-Marketing aspx.

Bäckbrö, J. and H. Nyström (2006), "Entrepreneurial marketing: Innovative value creation," Master's thesis, Jönköping International Business School, Jönköping University.

Branson, R. (2013), "Steve was never satisfied," Canadian Business, 86(16), 32.

Collinson, E. and E. Shaw (2001), "Entrepreneurial marketing - a historical perspective on development and practice," Management Decision, 39(9), 761-6.

Ely, T.E. and H.R. Hess (1937), Outlines of Economics, 6th edition, New York: Macmillan.

Hills, G.E. (1985), "Market analysis and marketing in new ventures: Venture capitalists' perceptions," in K. Vesper (ed.), Frontiers of Entrepreneurship Research, Wellesley, MA: Babson College, pp. 167-82.

Hills, G.E., C.M. Hultman and M.P. Miles (2008), "The evolution and development of entrepreneurial marketing," Journal of Small Business Management, 46(1), 103-4.

Hills, G.E., C.M. Hultman, S. Kraus and R. Schulte (2010), "History, theory and evidence of entrepreneurial marketing - an overview," International Journal of Entrepreneurship and Innovation Management, 11(1), 3-18.

Hisrich, R.D. (1992), "The need for marketing in entrepreneurship," Journal of Consumer Marketing, 9(3), 43-7.

Hisrich, R.D. (2000), Marketing, 2nd edition, New York: Barron's Educational Series, Inc.

Hisrich, R.D. (2014), Advanced Introduction to Entrepreneurship, Cheltenham, UK and Northampton, MA, USA: Edward Elgar Publishing.

Hisrich, R.D. and V. Ramadani (2017), Effective Entrepreneurial Management, Cham: Springer. 
Hisrich, R.D., P.M. Peters and A.D. Shepherd (2017), Entrepreneurship, 10th edition, New York: McGraw-Hill Education.

Ioniță, D. (2012), "Entrepreneurial marketing: A new approach for challenging times," Management and Marketing Challenges for the Knowledge Society, 7(1), 131-50.

Isaacson, W. (2011), Steve Jobs. New York: Simon \& Schuster.

Kerin, R., S. Hartley and W. Rudelius (2015), Marketing, 12th edition, New York: McGraw-Hill Education.

Kilby, P. (1971), Entrepreneurship and Economic Development, New York: Free Press.

Kotler, P. and G. Armstrong (2016), Principles of Marketing, 16th Global Edition, Boston, MA: Pearson.

Kotler, P. and L.K. Keller (2012), Marketing Management, 14th edition, Upper Saddle River, NJ: New Jersey: Pearson/Prentice Hall.

Kraus, S., R. Harms and M. Fink (2010), "Entrepreneurial marketing: Moving beyond marketing in new ventures," International Journal of Entrepreneurship and Innovation Management, 11(1), 19-34.

Lauterborn, R. (1990), "New marketing litany: 4Ps Passé: C-words take over," Advertising Age, 61(41), 26.

Miles, M.P. and J. Darroch (2006), "Large firms, entrepreneurial marketing processes, and the cycle of competitive advantage," European Journal of Marketing, 40(5/6), 485-501.

Morris, H.M. and G.W. Paul (1987), "The relationship between entrepreneurship and marketing in established firms," Journal of Business Venturing, 2(3), 247-59.

Morris, H.M., M. Schindehutte and R.W. La Forge (2002), "Entrepreneurial marketing: A construct for integrating emerging entrepreneurship and marketing perspectives," Journal of Marketing Theory and Practice, 10(4), 1-19.

Pride, M.W., J.R. Hughes and R.J. Kapoor (2014), Business, Andover, UK: Cengage Learning.

Ramadani, V. and C.R. Schneider (2013), Entrepreneurship in the Balkans: Diversity, Support and Prospects, Heidelberg: Springer.

Ries, A. and J. Trout (2006), Marketing Warfare, Boston, MA: Irwin/McGraw-Hill.

Schumpeter, J. (1952), Can Capitalism Survive?, New York: Harper \& Row.

Stokes, D. (2000), "Entrepreneurial marketing: A conceptualisation from qualitative research," Qualitative Market Research: An International Journal, 3(1), 47-54.

Veseli, N., V. Ramadani and G. Rexhepi (2010), Direct Marketing and Small Businesses, Saarbrucken: Lambert Academic Publishing. 